\title{
Telenzepine is at least 25 times more potent than pirenzepine - a dose response and comparative secretory study in man
}

\author{
W LONDONG, V LONDONG, A MEIERL, AND U VODERHOLZER \\ From the Chirurgische und Medizinische Kliniken Innenstadt, University of Munich, Munich, West Germany
}

SUMmaRY Telenzepine is an analogue of pirenzepine with a higher potency and similar selectivity for $\mathbf{M}_{1}$-receptors in animals. In this placebo controlled, double blind, randomised study mean peptone stimulated gastric acid secretion $(\bar{x} \pm S E M)$ of 10 male healthy subjects $(58 \pm 6 \mathrm{mmol}$ $\mathrm{H}^{+} / 3 \mathrm{~h}$ for placebo) was significantly and dose dependently inhibited by oral telenzepine ( $2 \mathrm{mg}$ : $31 \pm 5,3 \mathrm{mg}: 23 \pm 5,5 \mathrm{mg}: 21 \pm 4 \mathrm{mmol} \mathrm{H}+3 \mathrm{~h}$ ). Telenzepine 3 and $5 \mathrm{mg}$ were significantly stronger than pirenzepine $50 \mathrm{mg}$ orally $(37 \pm 8 \mathrm{mmol} \mathrm{H} / 3 \mathrm{~h})$. Mean percentage acid inhibition was $37 \%$ for pirenzepine, and 48,61 , and $64 \%$ for 2,3 , and $5 \mathrm{mg}$ telenzepine, respectively. Basal and peptone stimulated gastrin release was unaffected. Mean salivary output per three hours declined moderately from $156 \pm 45 \mathrm{~g}$ (placebo) to $136 \pm 45 \mathrm{~g}$ with pirenzepine and significantly to $88 \pm 28 \mathrm{~g}$, $95 \pm 39 \mathrm{~g}$ and $39 \pm 13 \mathrm{~g}$ with telenzepine 2,3 , and $5 \mathrm{mg}$, respectively. There was a parallel effect on $\mathrm{Na}^{+}, \mathrm{K}^{+}, \mathrm{Ca}^{++}$and amylase output in saliva. Near point vision was not altered by either drug. Pulse rates were lowered by both substances. Complaints of dry mouth were more frequent with telenzepine $5 \mathrm{mg}$. On a molar basis telenzepine proved to be a 25 and 50 times more potent inhibitor of gastric and salivary secretion, respectively.

Telenzepine is a new analogue of pirenzepine having an altered tricyclic structure and an unchanged side chain (Fig. 1). In animal studies, telenzepine was four to 10 times more potent than pirenzepine inhibiting gastric acid secretion.' It healed experimentally induced gastroduodenal ulcers more effectively and at lower doses than pirenzepine. ${ }^{2}$ Both compounds exhibited a similiar selectivity profile differing from that of atropine.' Therefore, telenzepine was considered to be a new $\mathbf{M}_{1}$-receptor antagonist, although receptor binding studies using telenzepine are lacking.

Pirenzepine has more selective inhibitory properties on oxyntic gastric glands and less antimuscarinic side effects than conventional antimuscarinics like atropine.$^{34}$ In an oral dose of 100 to $150 \mathrm{mg}$ daily pirenzepine proved to be superior to placebo and as

Address for correspondence: Prof Dr Walter Londong, Chirurgische Klinik Innenstadt und Chirurgische Poliklinik, University of Munich, Nussbaumstrasse 20, D-8000) Muenchen 2, West Germany.

Received for publication 11 November, 1986. effective as cimetidine in the treatment of patients with duodenal ulcer. ${ }^{34}$ Because of more pronounced antisecretory properties of telenzepine in animals' it was of interest to investigate its relationship of antimuscarinic effects and side effects in man. Therefore, we undertook this placebo controlled, double blind and randomised study in which the dose response of telenzepine 2,3 , and $5 \mathrm{mg}$ orally was compared with the standard oral dose of pirenzepine $50 \mathrm{mg}$ in 10 healthy male subjects. Peptone stimulated gastric acid secretion, gastrin release, spontaneous salivation, near point vision and peripheral pulse rates were synchronously measured.

\section{Methods}

\section{SUBJECTS}

Ten healthy male subjects with a median age of 25 years (range 21-31 years), a median body weight of $75 \mathrm{~kg}$ (range $64-90 \mathrm{~kg}$ ) and a median height of $185 \mathrm{~cm}$ (range 180-190 cm) participated in this trial. They had no abnormal physical findings including ECG 

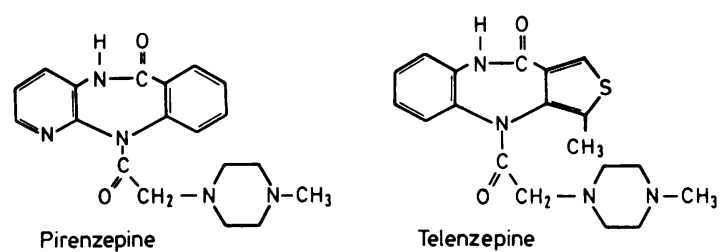

Fig. 1 Structural formula of pirenzepine and its analogue telenzepine having an altered tricyclic structure and an unchanged side-chain.

and no abnormal values of haematology, biochemistry, and urine analysis screen within 14 days before the first experiment. Criteria for exclusion were significant clinical illness and administration of investigational drug within the preceding four weeks, need for concomitant medication, conditions which could modify the absorption of the study medication, history of allergy, cardiac, renal, hepatic or significant gastrointestinal disease, history of drug addiction and excessive alcohol consumption. Each subject underwent a follow up laboratory screen not more than three days after the last experiment. All subjects gave written consent to participate in this study after full explanation by the investigator. The protocol of the study dated 20 July, 1984 was approved by the Ethical Committee of the Medical Faculty of the University of Munich on 19 October, 1984. The trial was conducted according to the Declarations of Helsinki and Tokyo.

Each subject participated in five experiments in which 2,3 , and $5 \mathrm{mg}$ telenzepine, $50 \mathrm{mg}$ pirenzepine and placebo were administered orally in the form of identical tablets (provided by Byk Gulden Company, D-7750 Konstanz, West Germany). The study was performed double blind and according to a predetermined randomisation code. The intervals between any two experiments were not less than four days, but not more than two weeks. Subjects were requested not to eat or to drink anything after $10 \mathrm{pm}$ the previous evening. Alcohol intake was prohibited the evening before.

\section{EXPERIMENTAL PROCEDURE}

Each experiment started at $7 \mathrm{am}$. An iv cannula for collection of blood samples was inserted in a forearm vein and secured. Isotonic saline was infused at a rate of $40 \mathrm{ml} / \mathrm{h}$ to keep the cannula patent. Blood for determination of gastrin and drug concentrations was taken before $(-5)$ and $45,90,120,150,180,210,240$, and 270 minutes after drug intake. At zero minutes tablets were swallowed with $50 \mathrm{ml}$ water. Eighty minutes after drug administration a double lumen gastric tube (Levine-type Ch 16) was placed in the stomach so that the tip of the tube was positioned in the fundus corpus area (in average $58.5 \mathrm{~cm}$ (range $56-61 \mathrm{~cm}$ ) below front teeth - that is, about $10 \mathrm{~cm}$ below the cardia. One hundred minutes after medication the gastric secretion test began with an intragastric instillation of $300 \mathrm{ml} 10 \%$ aqueous peptone solution (pH 5.5). Acid output was determined over a period of three hours by continuous titration according to Fordtran and Walsh ${ }^{5}$ modified by Becker ${ }^{6}$ using $1 \mathrm{~N}$ sodium hydroxide for automatic titration to an endpoint of $\mathrm{pH} 5 \cdot 5$. $^{7}$ During the test the subjects were lying in a left lateral position. To maintain a constant speed of circulation of 250-280 $\mathrm{ml} / \mathrm{min}$, smaller volumes of peptone solution were substituted throughout the test. At the end of each gastric secretion test the stomach was emptied by suction. Details of our method have already been described. ${ }^{4111}$

During each experiment the saliva of the subjects was collected by a standardised and continuous suction using a perfusor system (B Braun Melsungen AG, Melsungen/FRG, type 371 102) in a reverse direction. The saliva was aspirated through a small standardised tube (original perfusor tube no 872 296/0) positioned in the anterior oral cavity into a $50 \mathrm{ml}$ syringe to avoid evaporation. The speed of suction was adapted to the individual flow rate; on average the speed was $30-60 \mathrm{ml}$ per 30 minutes. The subjects were instructed neither to swallow nor to spit out saliva. Salivary output was measured in 30 minutes intervals by weighing. The concentrations of sodium and potassium were determined by flame photometry, calcium by colorimetric estimation using o-cresolphthalein complexone as indicator ${ }^{11}$ and $\alpha$-amylase by a direct spectrophotometric test using p-nitrophenyl $\alpha$-maltoside as substrate. ${ }^{12}$ Furthermore, accommodation was monitored by determining near point vision at definite intervals during the test; under standardised light conditions a Rodenstock accommodometer was used. We calculated the mean of the measurements of accommodation before medication in all five intraindividual comparisons; this was defined as zero point. The values after drug intake are given as difference from zero point. Peripheral pulse rates were recorded in a standardised manner.

Blood samples for determination of gastrin and drug concentrations were placed on ice. After clotting and centrifugation (at $4^{\circ} \mathrm{C}, 4000 \mathrm{~g}$ ) the serum phase was separated and stored at $-20^{\circ} \mathrm{C}$. Serum gastrin concentrations were measured by a sensitive radioimmunoassay ${ }^{13}$ using the specific antibody 4562 (kindly provided by Professor J F Rehfeld, Copenhagen, Denmark). Serum samples were analysed for concentrations of telenzepine using a gaschromatography-mass spectrometry assay, while pirenzepine was determined by radioimmunoassay. ${ }^{14}$ 


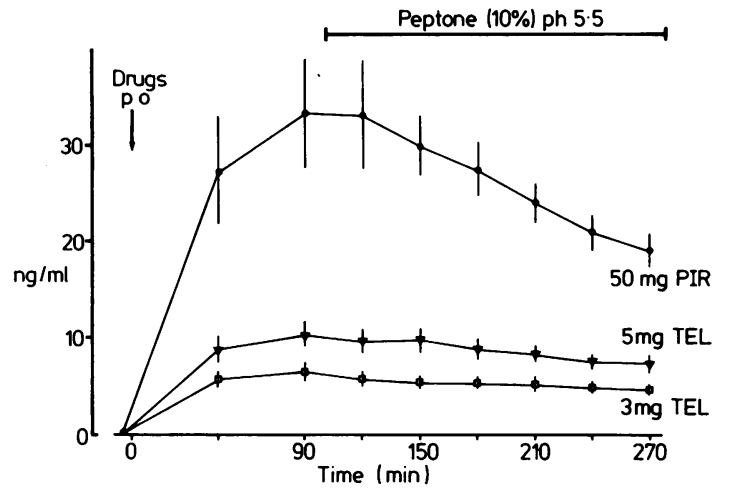

Fig. 2 Mean drug serum concentrations ( $\bar{x} \pm$ SEM) of 10 healthy male subjects after oral intake of $50 \mathrm{mg}$ pirenzepine (PIR), 3 and $5 \mathrm{mg}$ telenzepine (TEL) at time zero. Serum concentrations of $2 \mathrm{mg}$ telenzepine were not measured; they would have been at the lower detection limit. In this diagram peptone stimulation is shown to illustrate the relationship of drug concentrations and experimental phase.

STATISTICAL ANALYSIS

Statistical evaluation was made by using two sided Wilcoxon's matched-pairs rank test. Only values of $\mathrm{p} \leqq 0.01$ were considered significant. Results were expressed in the conventional way as mean \pm standard error or the mean $(\bar{x} \pm S E M)$.

\section{Results}

Figure 2 illustrates the mean drug serum concentrations of $50 \mathrm{mg}$ pirenzepine as well as those of 3 and $5 \mathrm{mg}$ telenzepine. Serum concentrations of $2 \mathrm{mg}$ telenzepine were not measured because the values would have been at the lower detection limit of the method used. Pirenzepine concentrations were in the lower normal range after a standard dose of $50 \mathrm{mg}$ pirenzepine orally.

Mean values of peptone stimulated gastric acid secretion per 15 minutes are shown in Figure 3 . There were significant reductions of peptone stimulated acid output after $50 \mathrm{mg}$ pirenzepine as well as after the three doses of telenzepine. Telenzepine proved to be more effective than $50 \mathrm{mg}$ pirenzepine and reduced acid output in a dose dependent manner. Synchronously measured basal and peptone stimulated serum gastrin concentrations were not significantly altered by either drug.

Peptone stimulated acid output per three hours $(\bar{x} \pm \mathrm{SEM})$ was significantly reduced $(\mathrm{p} \leqq 0 \cdot 01)$ from $58.1 \pm 5.6 \mathrm{mmol} \mathrm{H}^{+}$(placebo) to $36.8 \pm 7.6 \mathrm{mmol} \mathrm{H}^{+}$ by $50 \mathrm{mg}$ pirenzepine, to $30 \cdot 5 \pm 5 \cdot 3 \mathrm{mmol} \mathrm{H}^{+}$by $2 \mathrm{mg}$ telenzepine, $22.8 \pm 4.5 \mathrm{mmol} \mathrm{H}^{+}$by $3 \mathrm{mg}$ telenzepine and to $21 \cdot 2 \pm 3.9 \mathrm{mmol} \mathrm{H} \mathrm{H}^{+}$by $5 \mathrm{mg}$ telenzepine. The mean percentage inhibition was $37 \%$ for pirenzepine and 48,61 , and $64 \%$ for 2,3 , and $5 \mathrm{mg}$ telenzepine, respectively. The effect of 3 and $5 \mathrm{mg}$ telenzepine was significantly stronger than that of $2 \mathrm{mg}$ telenzepine and of $50 \mathrm{mg}$ pirenzepine ( $\mathrm{p} \leqq 0 \cdot 01$ ). On a molar basis telenzepine proved to be about 25 times more potent than pirenzepine to inhibit acid output. Mean peptone volumes which had to be added during the secretory studies did not show significant differences within the test with pirenzepine or telenzepine medication.

Histograms of salivary output per 30 minutes are given in Figure 4. Fifty milligrams pirenzepine had only a minor effect on reducing salivation, whereas the effect of 2,3 , and $5 \mathrm{mg}$ telenzepine was stronger being significant at different time intervals. The most dramatic effect was observed with $5 \mathrm{mg}$ telenzepine. Total saliva per three hours $(\bar{x} \pm$ SEM) was reduced from $156 \pm 45 \mathrm{~g}$ (placebo) to $136 \pm 45 \mathrm{~g}$ by pirenzepine and to $88 \pm 28 \mathrm{~g}, 95 \pm 39 \mathrm{~g}$, and $39 \pm 13 \mathrm{~g}$ by 2,3 , and $5 \mathrm{mg}$ telenzepine, respectively. Mean percentage inhibition of salivation was $13 \%$ for $50 \mathrm{mg}$ pirenzepine and 44,39 , and $75 \%$ for 2,3 , and $5 \mathrm{mg}$ telenzepine, respectively. The inhibition of salivation by the three telenzepine dosages was significant $(p \leqq 0 \cdot 01)$, but not strongly dose dependent. Only the difference between the inhibitory effect of $5 \mathrm{mg}$ proved to be significant $(\mathrm{p} \leqq 0.01)$ versus $50 \mathrm{mg}$ pirenzepine. On a molar basis telenzepine was more than 50 times more potent than pirenzepine in reducing salivation. There was a statistically obvious correlation between acid inhibition and reduction of salivation $(r=0.858$, $\mathrm{p} \leqq 0 \cdot 05)$.

Table 1 contains mean salivary output of sodium, potassium, calcium, and amylase per three hours. Whereas $50 \mathrm{mg}$ pirenzepine had negligible effects, more pronounced reductions were documented after telenzepine - being significant $(\mathrm{p} \leqq 0 \cdot 01)$ for sodium after $3 \mathrm{mg}$ as well as for sodium, potassium and calcium after $5 \mathrm{mg}$.

When monitoring near point vision (Fig. 5) we

Table 1 Mean salivary output per three hours $(\bar{x} \pm S E M)$ of electrolytes and amylase in 10 healthy male subjects

\begin{tabular}{|c|c|c|c|c|c|}
\hline & Placebo & $\begin{array}{l}50 m g \\
\text { Pir }\end{array}$ & $\begin{array}{l}2 \mathrm{mg} \\
\mathrm{Tel}\end{array}$ & $\begin{array}{l}3 \mathrm{mg} \\
\mathrm{Tel}\end{array}$ & $\begin{array}{l}5 \mathrm{mg} \\
\mathrm{Tel}\end{array}$ \\
\hline $\begin{array}{l}\text { Sodium } \\
(\mathrm{mmol} / 3 \mathrm{~h})\end{array}$ & $\begin{array}{l}3 \cdot 2 \\
\pm 1 \cdot 7\end{array}$ & $\begin{array}{l}2 \cdot 6 \\
\pm 1 \cdot 5\end{array}$ & $\begin{array}{l}1 \cdot 3 \\
\pm 0 \cdot 47\end{array}$ & $\begin{array}{l}1 \cdot 7^{*} \\
\pm 0.94\end{array}$ & $\begin{array}{l}0.53^{*} \\
\pm 0 \cdot 22\end{array}$ \\
\hline $\begin{array}{l}\text { Potassium } \\
\text { (mmol/3h) }\end{array}$ & $\begin{array}{l}2 \cdot 5 \\
\pm 0 \cdot 80\end{array}$ & $\begin{array}{l}2 \cdot 4 \\
\pm 0 \cdot 80\end{array}$ & $\begin{array}{l}1.6 \\
\pm 0.49\end{array}$ & $\begin{array}{l}1.7 \\
\pm 0.65\end{array}$ & $\begin{array}{l}0 \cdot 83^{*} \\
\pm 0 \cdot 26\end{array}$ \\
\hline $\begin{array}{l}\text { Calcium } \\
(\mathrm{mmol} / 3 \mathrm{~h})\end{array}$ & $\begin{array}{l}0.20 \\
\pm 0 \cdot 049\end{array}$ & $\begin{array}{l}0.20 \\
\pm 0 \cdot 054\end{array}$ & $\begin{array}{l}0 \cdot 12 \\
\pm 0 \cdot 031\end{array}$ & $\begin{array}{l}0 \cdot 13 \\
\pm 0 \cdot 041\end{array}$ & $\begin{array}{l}0.085^{*} \\
\pm 0 \cdot 031\end{array}$ \\
\hline $\begin{array}{l}\text { Amylase } \\
\text { (IU/3h) }\end{array}$ & $\begin{array}{l}11465 \\
\pm 5619\end{array}$ & $\begin{array}{l}12402 \\
\pm 6088\end{array}$ & $\begin{array}{l}6562 \\
\pm 2180\end{array}$ & $\begin{array}{l}10030 \\
\pm 4806\end{array}$ & $\begin{array}{l}4523 \\
\pm 1425\end{array}$ \\
\hline
\end{tabular}

${ }^{*}$ Significant $(\mathrm{p} \leqq 0 \cdot 01)$ versus placebo. 


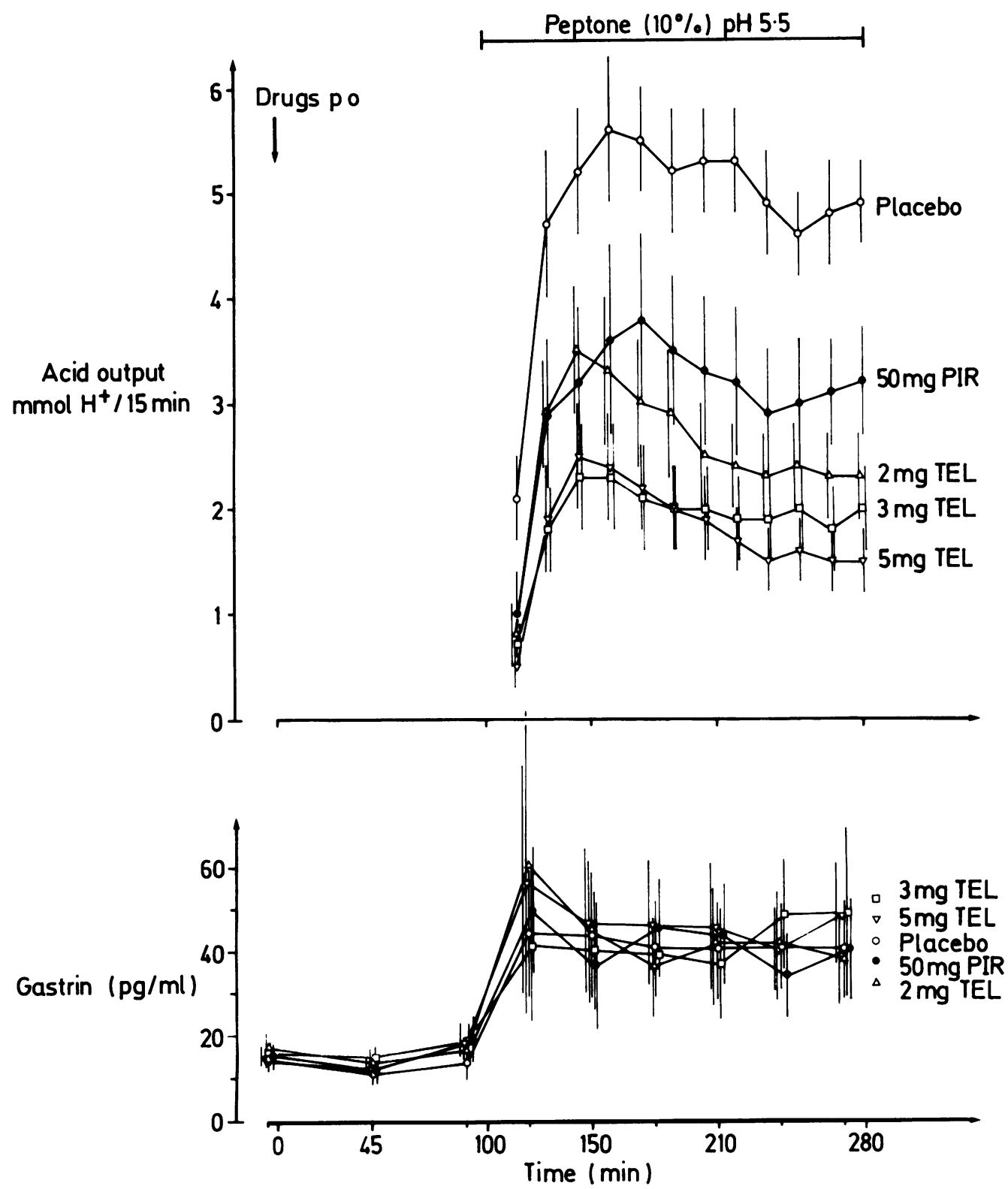

Fig. 3 Mean peptone stimulated gastric acid secretion per 15 min and synchronously measured serum gastrin release $(\overline{\times} \pm S E M)$ of 10 healthy male subjects. Acid inhibitory effect of pirenzepine (PIR) and telenzepine (TEL) was significant $(p \leqq 0 \cdot 01)$ within 30 min after the start of peptone stimulation.

could not detect any striking influence of either drug in the applied dosages. Peripheral pulse rates (Fig. 6) were lowered by either drug; the effects of $5 \mathrm{mg}$ telenzepine and $50 \mathrm{mg}$ pirenzepine were significant $(\mathrm{p} \leqq 0 \cdot 01)$ at 90 minutes and at 125 and 185 minutes postdosing, respectively. Table 2 summarises symptoms which the subjects were aware of during the double blind studies. Dry mouth occurred most frequently after $5 \mathrm{mg}$ telenzepine. Four of seven subjects receiving $5 \mathrm{mg}$ and two of three receiving $3 \mathrm{mg}$ telenzepine complained of dry mouth up to the afternoon or evening of the test day. In all other subjects who had dry mouth it occurred during an interval of 50 up to 250 minutes after drug intake. Dry 

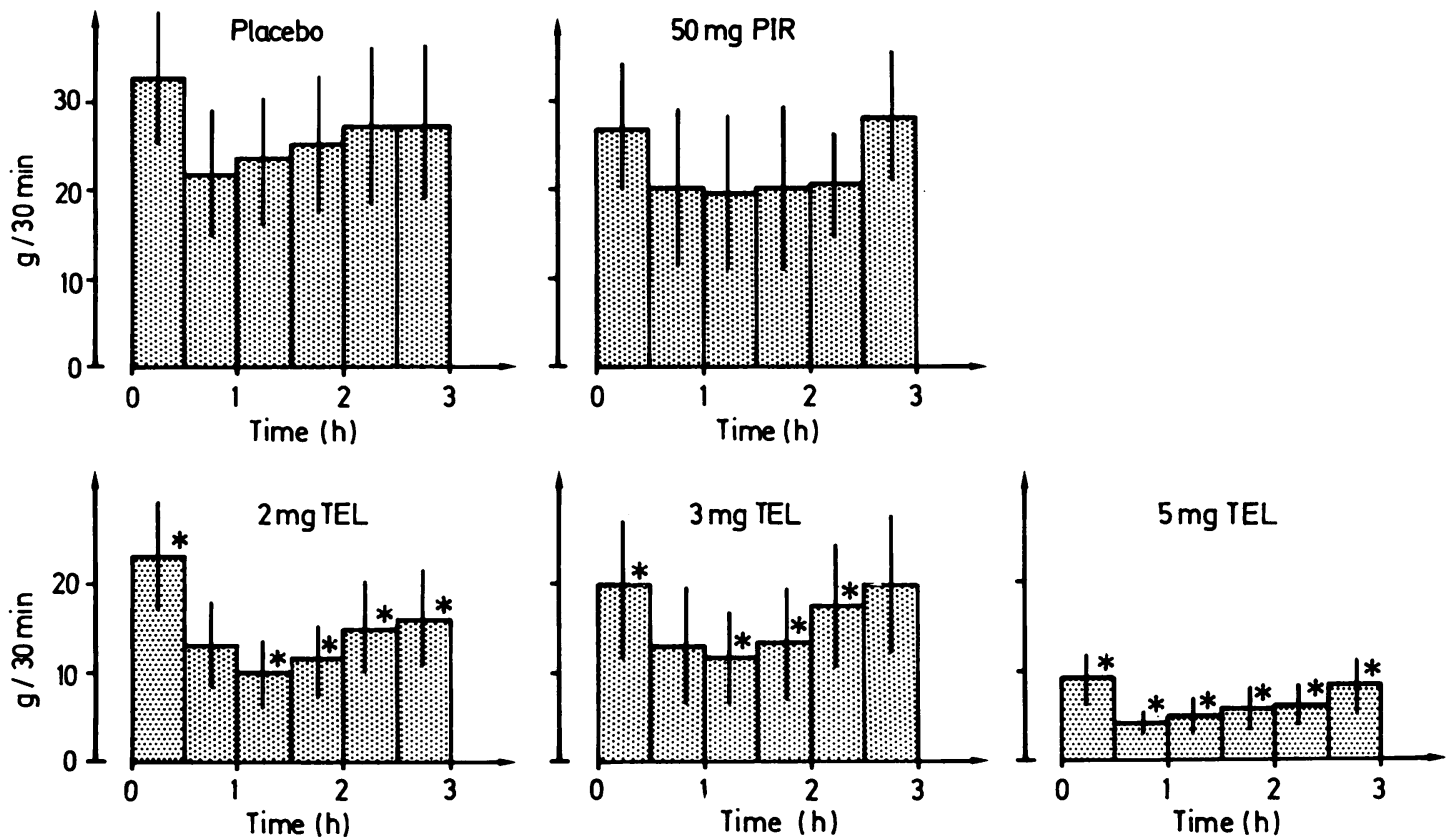

Fig. 4 Effects of pirenzepine (PIR) and telenzepine (TEL) on mean salivary output per 30 min $(\bar{x} \pm S E M)$ of 10 healthy male subjects. ${ }^{*}$ indicate significant differences $(p \leqq 0 \cdot 01)$ versus placebo.

eyes were specified by one subject during all five secretory tests and by two others after 2 and $5 \mathrm{mg}$ telenzepine. Blurred vision was short lasting and noticed only once after pirenzepine application. Loose stools were reported during the afternoon or the evening of the test day.

\section{Discussion}

In this placebo controlled, double blind and randomised study telenzepine inhibited dose dependently peptone stimulated gastric acid secretion of healthy male subjects. On a molar basis it proved to be about 25 times more potent than pirenzepine. Our result corresponds with data published by others who calculated a comparative potency. Eltze et al' found in in vitro and in vivo experiments in animals a factor of four to 10. Häcki et al' ${ }^{15}$ estimated a factor of more than 10 in basal and pentagastrin stimulated gastric acid secretion in man. Müller et al ${ }^{16}$ using sham feeding in man described a factor of 10 to 30 . The higher potency of telenzepine might be partly a consequence of a better bioavailability which has been proven recently to be on average $56 \%$ when a single oral dose was administered to healthy subjects (personal communication). Corresponding data for pirenzepine are 20 to $30 \% .{ }^{17}$ In this study the mean pirenzepine serum concentrations were rather low. ${ }^{18}$
This might be the reason of a comparatively low antisecretory effect of pirenzepine. A correlation between plasma concentrations of pirenzepine and its inhibitory effect on peptone stimulated gastric acid secretion has been shown recently in man. ${ }^{19}$

The method of peptone stimulation is suitable for pharmacodynamic studies. First, it has been shown to have a good reproducibility, being essential for

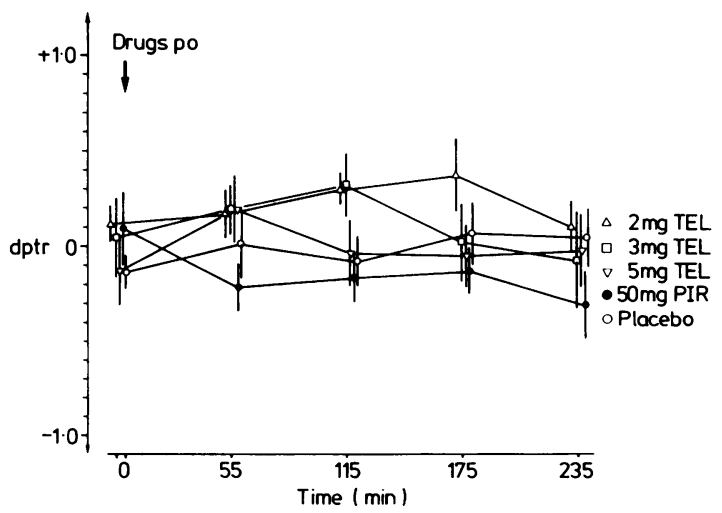

Fig. 5 Mean near point vision given as dioptrien (dptr, $\bar{x} \pm S E M)$ of 10 healthy male subjects as measured by accommodometer and calculated as difference from every individual zero point. 


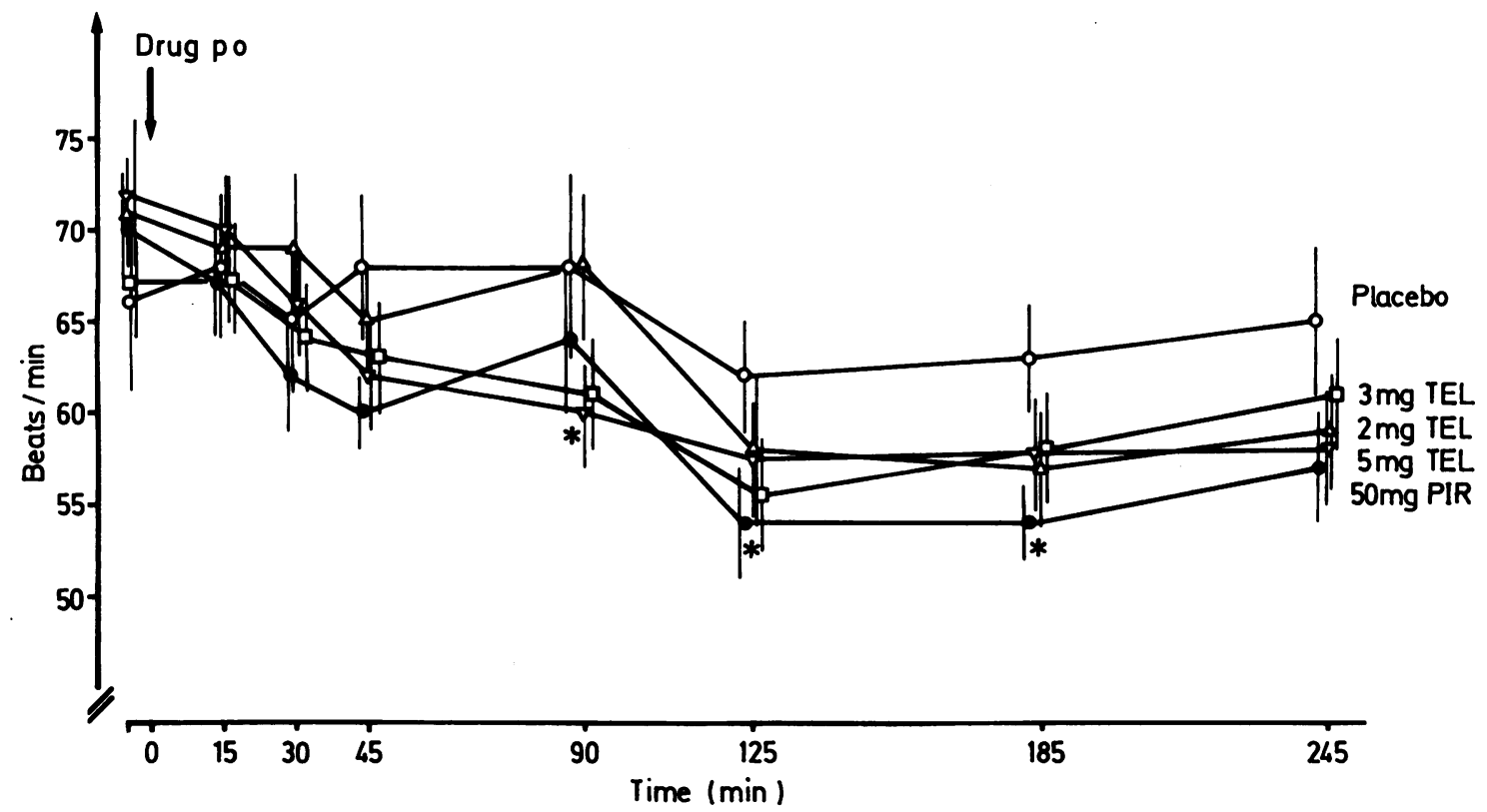

Fig. 6 Mean peripheral pulse rates $(\bar{x} \pm S E M)$ of 10 healthy male subjects receiving either pirenzepine (PIR) or telenzepine $(T E L)$. Significant differences versus placebo $(p \leqq 0.01)$ are indicated by asterisks for $5 \mathrm{mg}$ telenzepine at $90 \mathrm{~min}$ and for $50 \mathrm{mg}$ pirenzepine at 125 and $185 \mathrm{~min}$.

intraindividual comparisons, with a mean coefficient of variation of about $10 \%$ in man. ${ }^{6920}$ Second, it is a model for food stimulated gastric acid secretion and, contrary to pentagastrin test, allows simultaneous measurements of endogenous gastrin release. In this study, oral telenzepine had no influence on basal and peptone stimulated gastrin concentrations (Fig. 3). This is in agreement with findings on basal serum gastrin published by Häcki et al. ${ }^{15}$ In this respect, telenzepine shows the same behaviour as pirenzepine which does neither affect meal stimulated ${ }^{81021}$ nor sham feeding induced gastrin release in man. ${ }^{22}$ Both differ from atropine which enhances significantly serum gastrin in man after food stimulation ${ }^{2324}$ and sham feeding. ${ }^{22} 25$

In agreement with our results, Häcki et al ${ }^{15}$ showed

Table 2 Symptoms specified by the subjects $(n=10)$ during and/or after the secretory tests

\begin{tabular}{llllll}
\hline & Placebo & $\begin{array}{l}50 \mathrm{mg} \\
\text { Pir }\end{array}$ & $\begin{array}{l}2 \mathrm{mg} \\
\mathrm{Tel}\end{array}$ & $\begin{array}{l}3 \mathrm{mg} \\
\mathrm{Tel}\end{array}$ & $\begin{array}{l}5 \mathrm{mg} \\
\mathrm{Tel}\end{array}$ \\
\hline Dry mouth & 0 & 2 & 3 & 3 & $7^{*}$ \\
Dry eyes & 1 & 1 & 2 & 1 & 2 \\
Blurred vision & 0 & 1 & 0 & 0 & 0 \\
Loose Stools & 2 & 4 & 3 & 3 & 3 \\
Others $\dagger$ & 0 & 1 & 1 & 1 & 1 \\
\hline
\end{tabular}

${ }^{*} p \leqq 0.05$ versus placcbo (using Fisher’s cxact test); † such as tiredness, headache, and cuphoria. that $50 \mathrm{mg}$ pirenzepine given orally has less effect on salivary output in man than 3 and $5 \mathrm{mg}$ telenzepine which significantly and dose dependently inhibited salivation. Müller et al $^{16}$ also stated that a more pronounced reduction of salivation after $5 \mathrm{mg}$ telenzepine resulted in more frequent complaints of dry mouth, similar to our findings (Table 2). The parallel behaviour of a reduced output of electrolytes and amylase (Table 1 ) suggests that telenzepine mainly affects volume secretion of salivary glands. The correlation between inhibition of gastric acid secretion and salivation supports the assumption that telenzepine does not discriminate between muscarinic receptor sites at gastric and salivary glands.

Both drugs reduced heart rate; the effect of pirenzepine was more pronounced (Fig. 6). Significant reductions of heart rate have already been reported after parenteral ${ }^{126}$ or high oral doses $^{27}$ of pirenzepine. Blurred vision as a symptom of impaired accommodation was only once noticed after pirenzepine, but not after telenzepine (Table 2). Near point vision was not significantly altered by either drug (Fig. 5). In this respect, it is worth noting that an increase of mean pirenzepine plasma concentration from $40 \mathrm{ng} / \mathrm{ml}$ (normal therapeutic level) to $105 \mathrm{ng} / \mathrm{ml}$ (high therapeutic level) results in a significant reduction of near point vision. ${ }^{14}$

Loose stools were reported as symptom in similar 
frequency following placebo as well as drug experiments (Table 2). They are probably caused by transpyloric losses of hyperosmotic peptone solution and regularly observed using this test procedure. ${ }^{x-11}$ Rare symptoms like tiredness, headache and euphoria are unspecific. Central side effects of pirenzepine are very unlikely, as it penetrates blood brain barrier only to a small extent. ${ }^{2 *}$ Corresponding studies in cerebrospinal fluid of man using telenzepine are lacking.

Recent data ${ }^{1516}$ and our results with telenzepine have shown that structural alterations of the tricyclic structure of pirenzepine result in an increase of potency with regard to gastric acid inhibition in man. It would be interesting to study structure activity relationships of further pirenzepine analogues in order to develop even more potent and selective antimuscarinic drugs. In this connection, it should be mentioned that very recently another pirenzepine analogue with an altered side chain and an identical tricyclic structure (AF-DX 116) has been characterised by in vitro binding studies ${ }^{24}$ and by pharmacological studies in animals ${ }^{31}$ as a $\mathbf{M}_{2}$-receptor antagonist with cardioselective action.

In conclusion, telenzepine proved to be, on a molar basis, a 25 times more potent gastric antisecretagogue than pirenzepine under the conditions tested. Its closely related inhibition of salivation may limit the clinical application of higher doses of telenzepine as antiulcer drug.

The authors like to thank Dr E Sturm, Research Laboratories of Byk Gulden Company, Konstanz/ FRG, and Dr P Tanswell, Department of Biochemistry, Dr Karl Thomae GmbH, Biberach/ FRG, for measuring drug serum concentrations. This study has been published as abstract no 30 in Trends Pharmacol Sci 1986; suppl February: 89.

\section{References}

1 Eltze M, Gönne S, Riedel R, Schlotke B, Schudt C, Simon WA. Pharmacological evidence for selective inhibition of gastric acid secretion by telenzepine, a new antimuscarinic drug. Eur J Pharmacol 1985; 112: 211-24.

2 Investigator's brochure on telenzepine ( $B Y$ 803). Konstanz: Byk Gulden Pharmazeutika, 1984.

3 Londong W. Anticholinergics for peptic ulcer - a renaissance? Hepato-Gastroenterol 1982; 29: 40-6.

4 Carmine AA, Pakes GE, Brogden RN, Heel RC, Speight TM, Avery GS. Pirenzepine. A review of its pharmacology and therapeutic use in peptic ulcer disease and other allied diseases. Drugs 1985; 30: 85-126.

5 Fordtran JS, Walsh JH. Gastric acid secretion rate and buffer content of the stomach after eating: results in normal subjects and in patients with duodenal ulcer. J Clin Invest 1973; 52: 645-57.

6 Becker HD. Methodischer Fortschritt in der Funktionsdiagnostik des Magens: Magensekretionsanalyse, intragastrale Titration, endokrine Provokationstests. Z Gastroenterol 1978; 16: 118-25.

7 Konturek SJ, Biernat J, Oleksy J. Serum gastrin and gastric responses to meals at various $\mathrm{pH}$ levels in man. Gut 1974; 15: 526-30.

8 Londong $\mathrm{W}$, Londong $\mathrm{V}$, Ruthe $\mathrm{C}$, Weizert $\mathrm{P}$. Complete inhibition of food-stimulated gastric acid secretion by combined application of pirenzepine and ranitidine. Gut 1981; 22: 542-8.

9 Londong W, Londong V, Cederberg C, Steffen H. Dose-response study of omeprazole on meal-stimulated gastric acid secretion and gastrin release. Gastroenterology 1983; 85: 1373-8.

10 Londong W, Londong V, Prechtl R, Weber T, von Werder K. Interactions of cimetidine and pirenzepine on peptone-stimulated gastric acid secretion in man. Scand J Gastroenterol 1980; 15: suppl 66: 103-12.

11 Ray Sarkar BC, Chauhan UPS. A new method for determining micro quantities of calcium in biological materials. Anal Biochem 1967; 20: 155-66.

12 Gillard BK, Markman HC, Feig SA. Direct spectrophotometric determination of $\alpha$-amylase activity in saliva, with p-nitrophenyl $\alpha$-maltoside as substrate. Clin Chem 1977; 23: 2279-82.

13 Londong W, Geier E, Feifel G, Forell MM. Hypoglykämieinduzierte Gastrinfreisetzung nach Vagotomie. Z Gastroenterol 1975; 13: 418-23.

14 Tanswell P, Kasper W, Zahn G. Automated monoclonal radioimmunoassays for pirenzepine, a selective muscarinic receptor antagonist, in plasma and urine. J Immunol Meth 1986; 93: 247-58.

15 Häcki WH, Schulthess HK, Schalch E, Flückiger A, Valli C. Vergleich der Wirksamkeit von Pirenzepin und Telenzepin auf die Magen- und Speichelsekretion, auf Pupillenmotorik sowie auf Gastrin und pankreatisches Polypeptid beim Menschen. Schweiz Med Wochenschr 1985; 115: 1033-4.

16 Müller P, Damman H-G, Simon B. Telenzepin hemmt dosisabhängig die durch Scheinfütterung stimulierte menschliche Säure- und Speichelsekretion. Z Gastroenterol 1986; 115: 152-6.

17 Hammer R, Bozler G, Zimmer A, Koss FW. Pharmakokinetik und Metabolismus von Pirenzepin beim Menschen. Therapiewoche 1977; 27: 1575-93.

18 Bozler G, Hammer $R$. An international pharmacokinetic study on pirenzepine following a single oral dose. Scand J Gastroenterol 1980; 15: suppl 66: 27-32.

19 Londong W, Londong V, Tanswell P, Voderholzer U. Pharmakodynamische Studie zur Wirksamkeit von Pirenzepin bei mehrtägiger Therapie. Klin Wochenschr 1985; 63: suppl IV: 168.

20 Bodemar G, Walan A, Lundquist G. Food-stimulated acid secretion measured by intragastric titration with bicarbonate in patients with duodenal and gastric ulcer disease and in controls. Scand J Gastroenterol 1978; 13: 911-8.

21 El-Sabbagh HN, Bloom SR, Adrian TE, Prinz RA, Baron JH, Welbourne RB. The effect of pirenzepine on 
meal-stimulated gastrointestinal hormones. Scand $J$ Gastroenterol 1980; 15: suppl 66: 57-61.

22 Konturek SJ, Obtulowicz W, Kwiecien N, et al. Effects of pirenzepine and atropine on gastric secretory and plasma hormonal responses to sham-feeding in patients with duodenal ulcer. Scand J Gastroenterol 1980; 15: suppl 66: 63-9.

23 Walsh JH, Yalow RS, Berson SA. The effect of atropine on plasma gastrin response to feeding. Gastroenterology 1971; 60: 16-21.

24 Becker HD, Reeder DD, Thompson JC. Effect of atropine on basal and food-stimulated serum gastrin levels in man. Surgery 1974; 75: 701-4.

25 Feldman M, Richardson CT, Taylor IL, Walsh JH. Effect of atropine on vagal release of gastrin and pancreatic polypeptide. J Clin Invest 1979; 63: 294-8.

26 Stacher G, Steininger H, Bauer P, Ehn I, Schmierer G. Die Wirkung von intramuskulärem Pirenzepin, Atropin und Placebo auf die mahlzeitstimulierte Motilität des
Kolons. Eine Doppelblindstudie. In: Blum AL, Hammer R, eds. Die Behandlung des Ulcus pepticum mit Pirenzepin. Gräfelfing: Demeter Verlag, 1979: 139-44.

27 Fink M, Irwin P. EEG and behavioural effects of pirenzepine in normal volunteers. Scand J Gastroenterol 1980; 15: suppl 66: 39-46.

28 Jaup BH, Blomstrand C. Cerebro-spinal fluid concentrations of pirenzepine after therapeutic dosage. Scand J Gastroenterol 1980; suppl 66: 35-7.

29 Hammer R, Giraldo E, Schiavi GB, Monferini E, Ladinsky $\mathrm{H}$. Binding profile of a novel cardioselective muscarine receptor antagonist, AF-DX 116, to membranes of peripheral tissues and brain in the rat. Life Sci 1986; 38: 1653-62.

30 Giachetti A, Micheletti R, Montagna E. Cardioselective profile of AF-DX 116, a muscarine $\mathbf{M}_{2}$-receptor antagonist. Life Sci 1986; 38: 1663-72. 